\title{
Effect of Al-doping on the Optical Properties of ZnO Thin Film Prepared by Thermal Evaporation Technique
}

\author{
Musaab Khudhr M., Khalid Haneen Abass \\ Department of Physics, College of Education for Pure Science, University of Babylon, Iraq \\ E-mail: musabali33@yahoo.com, kalidhanin@yahoo.com
}

Keywords: ZnO:Al , Optical properties, Thermal evaporation technique.

\begin{abstract}
Aluminum doped $\mathrm{ZnO}$ (AZO) thin films doped has been prepared by thermal evaporation method onto glass substrates. The optical characterization has been studied by UV-Visible Spectrophotometer in the range (300-1100) $\mathrm{nm}$. The transmittance increased with increasing Aldoping, while absorption decreases with increasing Al-doping content. The energy gap $\left(\mathrm{E}_{\mathrm{g}}\right)$ values increased with increasing Al-doped in the $\mathrm{ZnO}: \mathrm{Al}$ thin films. The refractive index, extinction coefficient, and real and imaginary dielectric constants obtained results show that doping content strongly affects the optical parameters of AZO thin films. Optical constants tend to decrease with increasing doping content.
\end{abstract}

\section{Introduction}

$\mathrm{ZnO}$ is an II-VI transparent conducting oxide (TCO) touted as a material of choice for shortwavelength optoelectronics [1-2]. This semiconductor has several favorable properties: good transparency, high electron mobility, wide and direct band gap of $3.37 \mathrm{eV}$ at $300 \mathrm{~K} \mathrm{[3].} \mathrm{ZnO}$ is an n-type semiconductor and its conductivity can be controlled by thermal treatment or by adequate doping [4]. $\mathrm{ZnO}$ thin films have attracted considerable interest in recent years for application such as: transparent conducting material in liquid crystal displays [5], solar cell [6], gas sensors [7], and catalyzers [8]. Various techniques such as molecular beam epitaxy (MBE) [9], pulsed laser deposition (PLD) [10], magnetron sputtering [11], chemical vapor deposition (CVD) [12], atomic layer deposition [13], electron beam evaporation [14], hydrothermal method [15], and sol-gel process [16] have been applied to $\mathrm{ZnO}$ thin film preparation.

Many researches of Al-doped $\mathrm{ZnO}$ thin films are presented. The Al-doped $\mathrm{ZnO}$ thin film showed high transmittance and crystallinity [17].

In this work, it study the optical properties of $\mathrm{ZnO}$ :Al thin films prepared by thermal evaporation method.

\section{Experimental Techniques}

Zinc Oxide and Aluminum (99.99\% purity) were mixed at varying doping percentages of Aluminum $(0,0.002,0.004,0.006)$ wt. $\%$. Glass substrate was cleaned by distilled water and ethanol to remove surface contaminants and allowed to dry completely. The substrate was then mounted on a rotating substrate holder and the compound was then placed in a Molybdenum boat in Thermal evaporation system. The chamber was covered tightly and pumped down to $1 \times 10^{-7}$ mbar. Thickness of the thin films has been measured by the optical thin film measurement and found to be $125 \mathrm{~nm}$. The optical properties have been studied by UV-Visible Spectrophotometer in the rang (300-1100) nm.

\section{Results and discussion}

The optical properties of pure $\mathrm{ZnO}$ and have doped with different content of $\mathrm{Al}(0,0.002$, $0.004,0.006)$ wt. $\%$ at thickness $125 \mathrm{~nm}$ with annealing temperature at $573 \mathrm{~K}$ were investigated using UV-Visible Spectrophotometer in the range (300-1100) $\mathrm{nm}$. 
In general, we can observe that the transmittance increase with increasing wavelength for all prepared thin films. Fig. 1 shows the transmittance spectra of pure and Al-doped $\mathrm{ZnO}$ thin films with different content of Al. This result may be due to the reduction of the voids in the sample and the improvement of the homogeneous structure with uniformly distributed particles, thereby increasing the optical scattering. The increased optical transmittance is related to the crystallinity of the film, which is in accordance with the findings of workers Kim H. et al. [18] and E. M. Mkawi et al. [17].

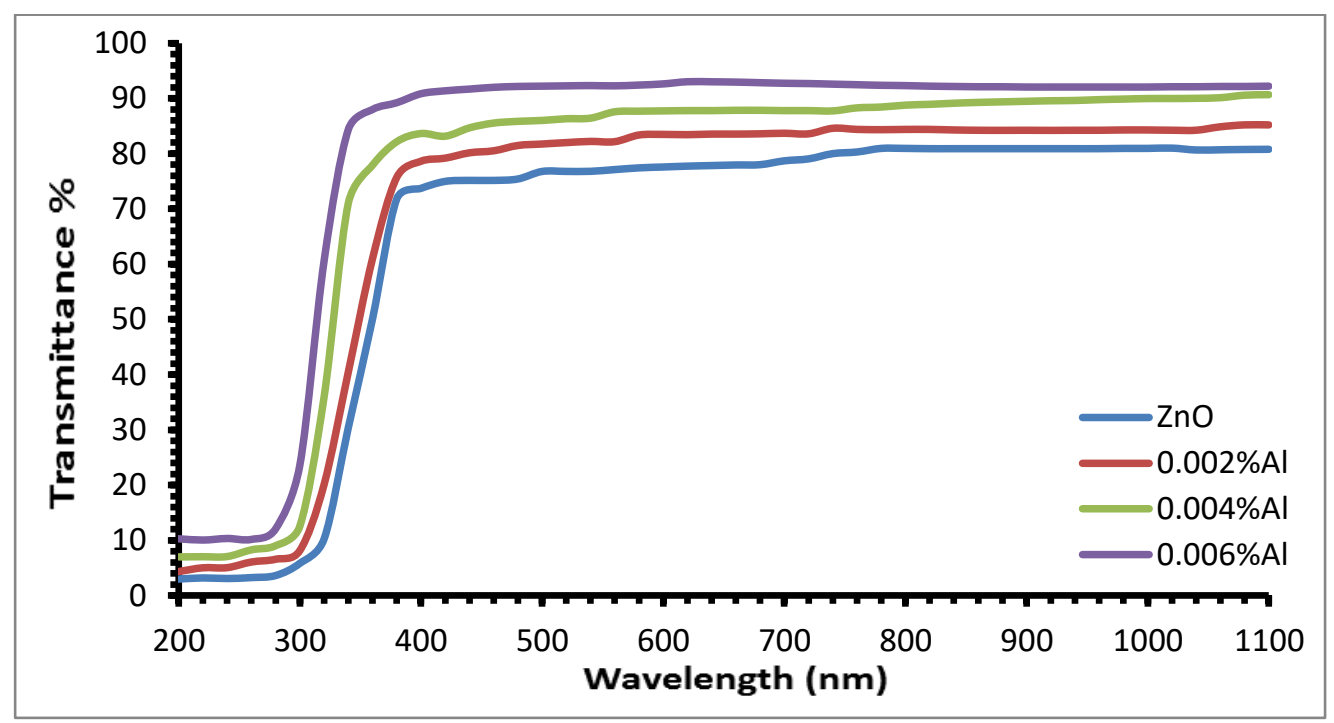

Fig. 1: Transmittance spectra as a function of wavelength of $\mathrm{ZnO}$ :Al thin films.

Fig. 2 shows the absorbance spectra of pure and Al-doped $\mathrm{ZnO}$ with different content of Al. From this figure, it can observe that the absorbance decreased with increasing Al-doped $\mathrm{ZnO}$ thin films.

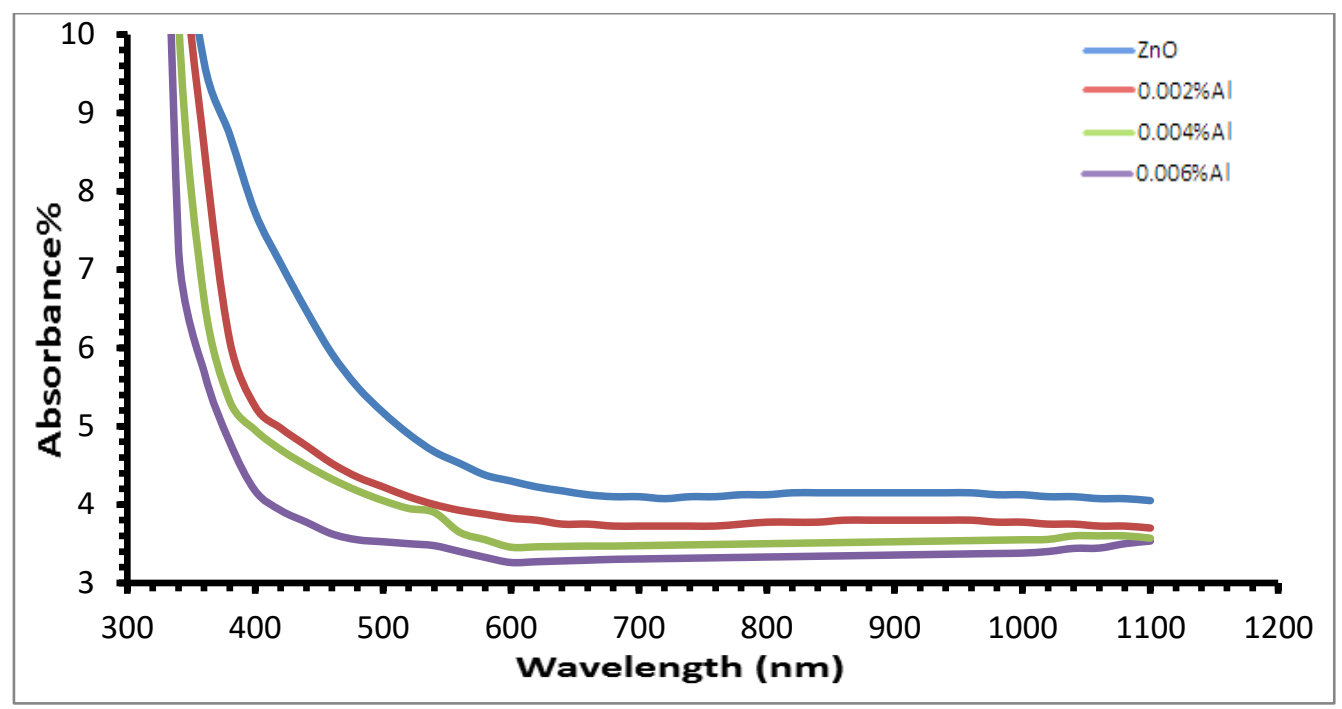

Fig. 2:The absorbance spectra as a function of wavelength of $\mathrm{ZnO}$ :Al thin films

The absorption coefficient $(\alpha)$ of $\mathrm{ZnO}$ :Al thin films system has calculated by using equation [19]:

$$
\alpha=2.303 \frac{\mathrm{A}}{\mathrm{t}}
$$

In general, we can observe that the absorption coefficient decreased with decreasing wavelength for all prepared thin films as shown in Fig. 3 that represents the relationship between 
the absorption coefficient spectra of pure and doped $\mathrm{ZnO}$ with different content of $\mathrm{Al}$ and wavelength. This result is agrees with the findings of other workers Mujdat C. et. al [20].

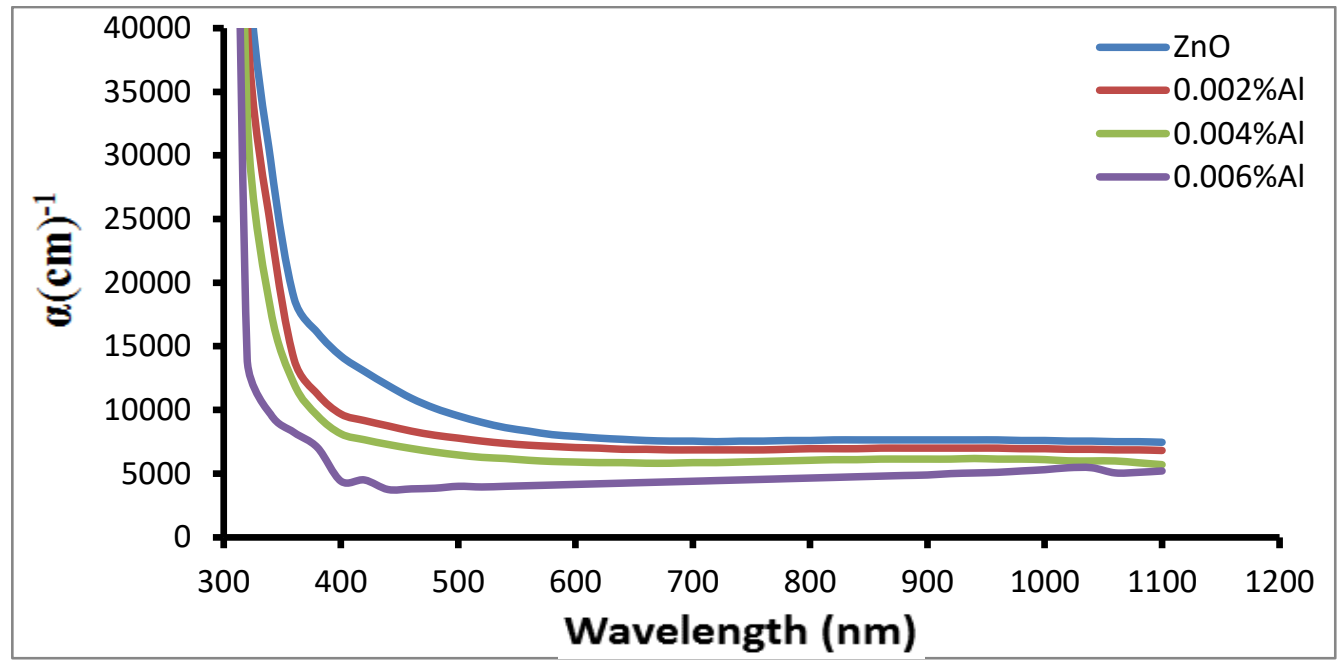

Fig. 3: The absorption coefficient spectra as a function of wavelength for $\mathrm{ZnO}$ : Al thin films.

The optical energy gap of $\mathrm{ZnO}: \mathrm{Al}$ thin films system has determined by using equation [21]:

$$
\alpha h v \approx\left[h v-E_{g}\right]^{1 / 2}
$$

The plot of $(\alpha h v)^{2}$ with energy $(\mathrm{h} v)$ indicates that $\mathrm{ZnO}$ films are direct transition type semiconductors at all thin films. The photon energy at the point where $(\alpha h v)^{2}$ is zero is $E_{g}$.

From the Fig. 4, shows the energy gaps of pure and Al-doped $\mathrm{ZnO}$ thin films with $(0.002$, 0.004, and 0.006)wt.\% aluminum. An obvious increase is observed for the values of the energy gap with the increase of the $\mathrm{Al}$ content. This increase is explained by the preposition that the $\mathrm{ZnO}: \mathrm{Al}$ films are semiconductors in which the Fermi level lies in the conducive band which means that the levels at the bottom of the conductivity band are occupied by electrons and the shielding of electronic traveling to these levels. These results show a good agreement with the findings of research Youssef A. et. al [22]. These results are listed in Table 1.

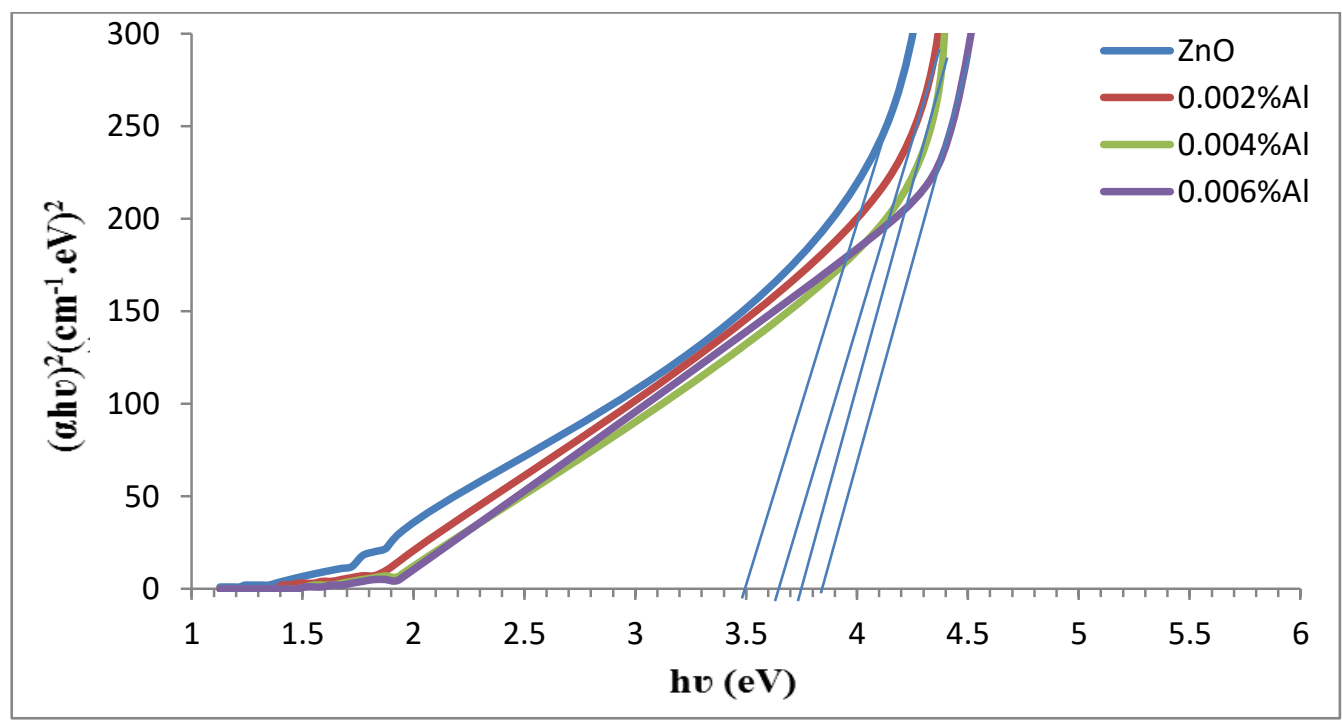

Fig. 4: A plots of $(\alpha h v)^{2}$ verses photon energy (hv) of $\mathrm{ZnO}$ : Al thin films. 
Table 1: The optical energy gap of Al-doping $\mathrm{ZnO}$ thin films.

\begin{tabular}{|c|c|}
\hline Type of thin film & Optical energy gap (eV) \\
\hline ZnO & 3.5 \\
\hline ZnO:0.002\% Al & 3.65 \\
\hline ZnO: $0.004 \%$ Al & 3.75 \\
\hline ZnO: $0.006 \%$ Al & 3.85 \\
\hline
\end{tabular}

The refractive index (n) of $\mathrm{ZnO}: \mathrm{Al}$ thin films system has determined by using equation [23]:

$$
n=\left(\frac{4 R}{(R-1)^{2}}-k^{2}\right)^{1 / 2}+\frac{(R+1)}{(R-1)}
$$

The behavior of the extinction coefficient of pure and Al-doped $\mathrm{ZnO}$ thin films with different content of Al. The variation of the refractive index versus wavelength in the range (300-1100) nm were shown in Fig. 5. It can notice from the figure that the refractive index, in general, decreases with the increasing of $\mathrm{Al}$ content may be mainly attributed to an increase of the carrier content in the $\mathrm{ZnO}$ :Al films. For all the films, this is in agreement with S. Bandyopadhyay et al. [24] and Xue et al. [25].

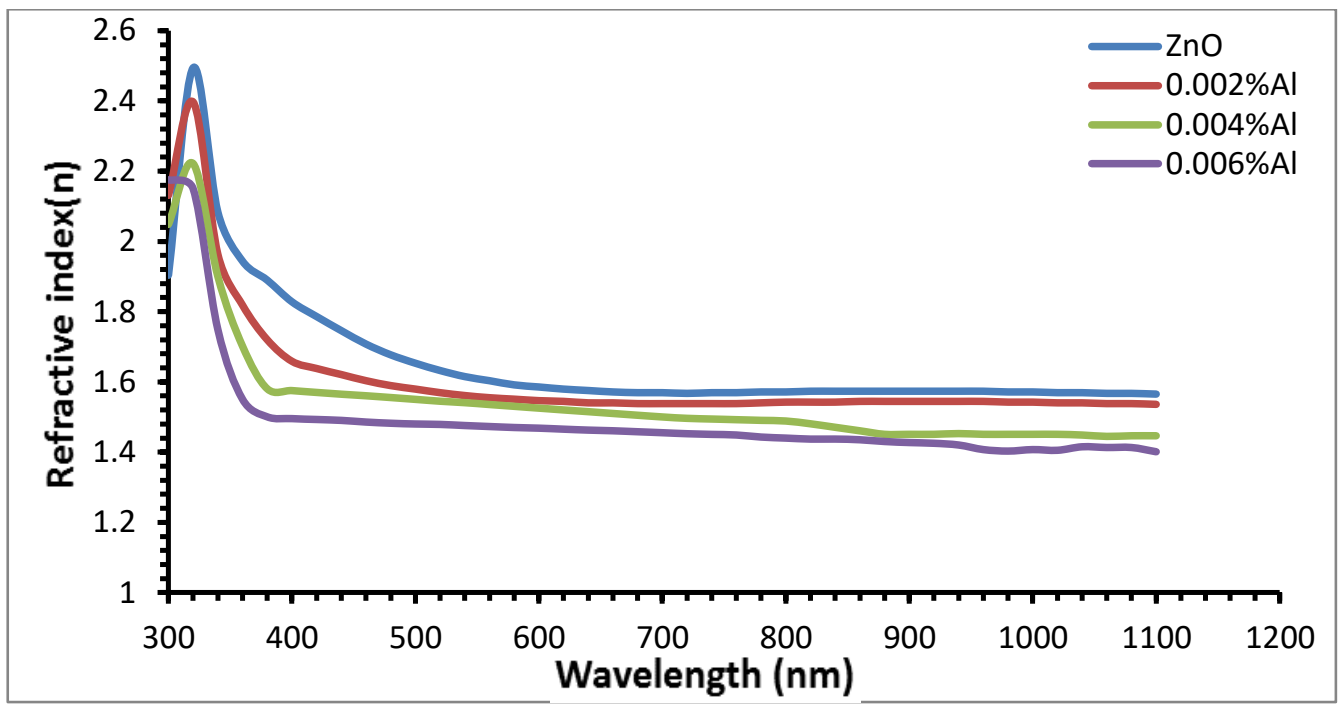

Fig. 5: Variation of refractive index with wavelength for pure and Al-doped $\mathrm{ZnO}$ thin films.

The extinction coefficient $\left(\mathrm{k}_{\mathrm{o}}\right)$ for $\mathrm{ZnO}: \mathrm{Al}$ thin films system has determined by using equation [26]:

$$
\mathrm{k}_{\mathrm{o}}=\frac{\alpha \lambda}{4 \pi}
$$

In general, we can observe that the extinction coefficient decrease with increasing of $\mathrm{Al}$ content for all prepared thin films. Fig. 6 shows the extinction coefficient of pure and Al-doped $\mathrm{ZnO}$ with different content of Al. This is in agreement with Min S. K. et al [27]. 


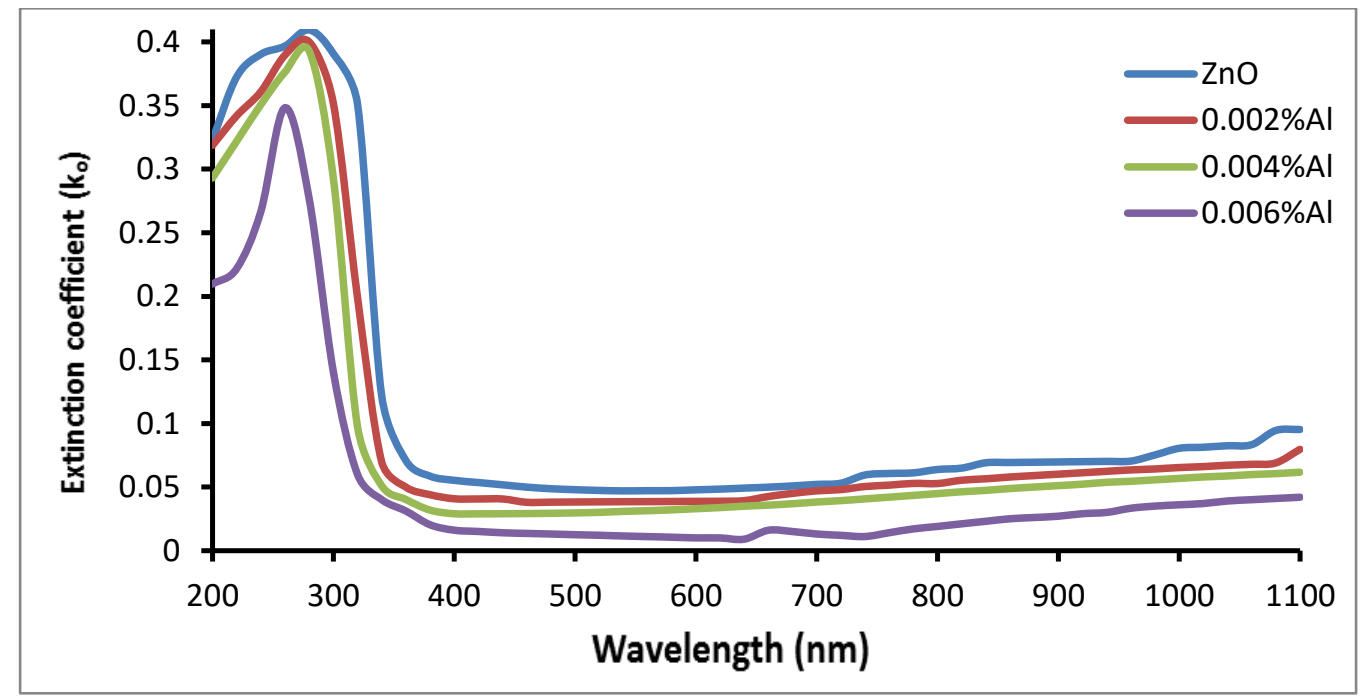

Fig. 6: Variation of extinction coefficient with wavelength of $\mathrm{ZnO}$ : Al thin films.

The real and imaginary dielectric constants $\left(\varepsilon_{\mathrm{r}}\right.$ and $\left.\varepsilon_{\mathrm{i}}\right)$ of $\mathrm{ZnO}: \mathrm{Al}$ thin films system have determined by using equations [26]:

$$
\begin{aligned}
& \varepsilon_{\mathrm{r}}=n^{2}-k^{2} \\
& \varepsilon_{\mathrm{i}}=2 n k
\end{aligned}
$$

The variation of real $\left(\varepsilon_{\mathrm{r}}\right)$ and imaginary $\left(\varepsilon_{\mathrm{i}}\right)$ parts of dielectric constant values versus wavelength for pure and $\mathrm{Al}$-doped $\mathrm{ZnO}$ with different $\mathrm{Al}$ content. In general, It can observe that the $\varepsilon_{\mathrm{r}}$ and $\varepsilon_{\mathrm{i}}$ decrease with increasing of $\mathrm{Al}$ content for all prepared thin films. Figs.(7-8) shows the $\varepsilon_{\mathrm{r}}$ and $\varepsilon_{\mathrm{i}}$ of pure and $\mathrm{Al}$-doped $\mathrm{ZnO}$ with different content of $\mathrm{Al}$. This is in agreement with Mujdat $\mathrm{C}$. et. al [20].

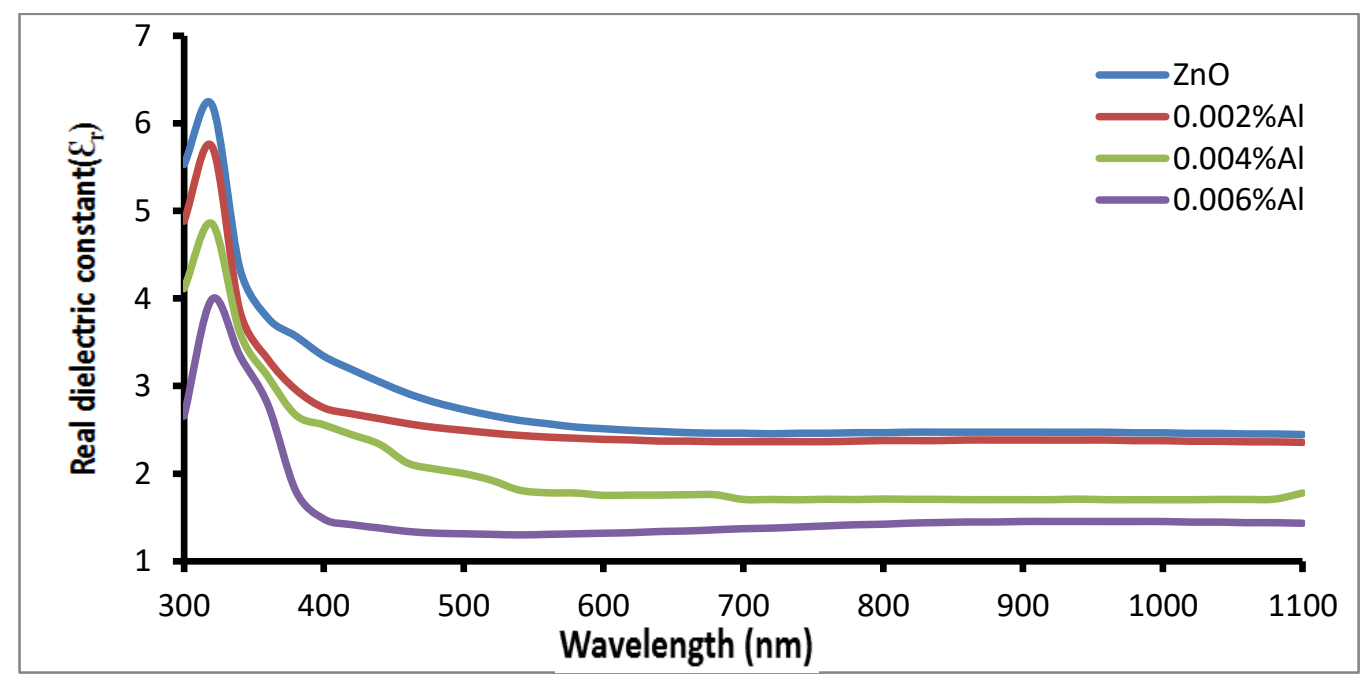

Fig. 7: Variation of $\varepsilon_{\mathrm{r}}$ with wavelength of $\mathrm{ZnO}$ :Al thin films. 


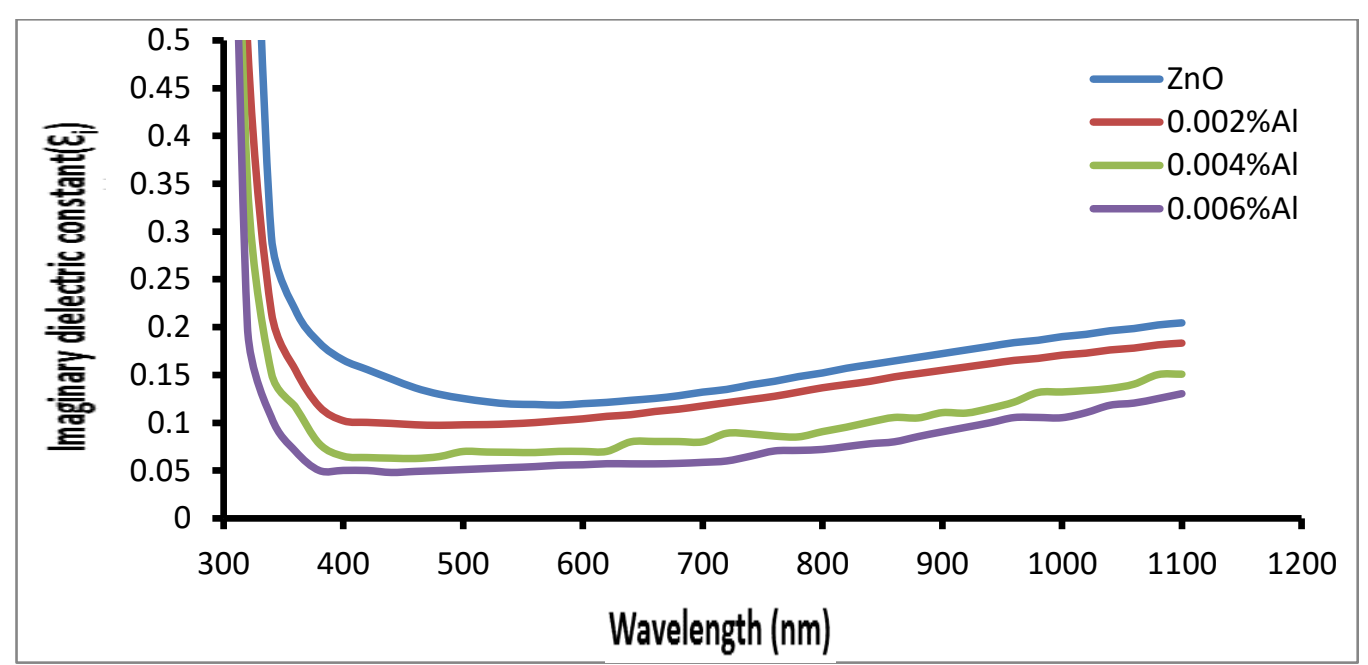

Fig. 8: Variation of $\varepsilon_{i}$ with wavelength of $\mathrm{ZnO}$ :Al thin films.

\section{Conclusions}

1- The transmittance spectra increased with the increasing of Al-doped $\mathrm{ZnO}$ thin film, the highest transmission is $(92 \%)$, while the absorption spectra decrease with increasing Al-doping. These films more suitable for solar cell fabrication.

2- The value of the band gap is enhanced from $3.5 \mathrm{eV}$ for un-doped $\mathrm{ZnO}$ to $3.85 \mathrm{eV}$ for $\mathrm{ZnO}: 0.006 \% \mathrm{Al}$.

3- The absorption coefficient, refractive index, extinction coefficient, and the real and imaginary parts of dielectric constant are obtained results show that doping content strongly affects the optical parameters of AZO thin films. Optical constants tend to decrease with increasing doping content.

\section{References}

[1] Yu-lin Wang, "Fabrication and Characterization of Zinc Oxide Light Emitting Diodes" Ph.D. Thesis, University of Florida (2009).

[2] H. Kumar Y. Dav, K. Sreenivas, and V. Guptaa, "Influence of Post Deposition, Annealing on the Structural and Optical Properties of Mn doped ZnO Thin Films", Journal of Applied Physics, 99 (2006) p.083507.

[3] B. Kumar, T. Rao, "Effect of Substrate Temperature on Structural Properties of Nanostructur Zinc Oxide Thin Films Prepared by Reactive DC Magnetron Sputtering”, Digest Journal of Nanomaterials and Biostructures, 6(3) (2011) 1281-1287.

[4] K. Jang, H. Park, S. Jung, N. V. Duy, and Y. Kim, “Optical and electrical properties of 2 wt.\% $\mathrm{Al}_{2} \mathrm{O}_{3}$-doped $\mathrm{ZnO}$ films and characteristics of Al-doped $\mathrm{ZnO}$ thin-film transistors with ultra-thin gate insulators", Thin Solid Films, 518 (2010) 2808-2811.

[5] B. Y. Oh, M. C. Jeong, T. H. Moon, M. W. Lee, and J. M. Myoung, J. Appl. Phys. 99 (2006) 124505.

[6] K. Keis, E. Magnusson, H.Lindström, S. E. Lindquist, A. Hagfeldt, Sol. Energy Mater. Sol. Cells 73 (2002) 51.

[7] H. J. Lim, D. Yong, Y. J. Oha, "Gas sensing properties of $\mathrm{ZnO}$ thin films prepared by microcontact printing”, Sensor Actuator A, 125 (2006) 405-410. 
[8] M. Miki-Yoshida, V. Collins-Martınez, P. Amezaga-Madrid, A. Aguilar-Elguezabal, "Thin films of photocatalytic $\mathrm{TiO}_{2}$ and $\mathrm{ZnO}$ deposited inside a tubing by spray pyrolysis", Thin Solid Films 419 (2002) 60-64.

[9] K. G. Yim, M. Y. Cho, S. M. Jeon, M. S. Kim, and J. Y. Leem, J. Korean Phys. Soc., 58 (2011) 520.

[10] E. M. Kaidashev, M. Lorenz, H. Wenckstern, A. Rahm, H.C. Semmelhack, K.H. Han, G. Benndorf, C. Bundesmann, H. Hochmuth, and M. Grundmann, Appl. Phys. Lett., 82(2003) 3901.

[11] P. F. Carcia, R. S. Mclean, M. H. Reilly, and G. Nunes, Appl. Phys. Lett 82 (2003) 1117.

[12] C. R. Gorla, N. W. Emanetoglu, S. Liang, W. E. Mayo, Y. Lu, M. Wraback, and H. Shen, J. Appl. Phys., 85 (1999) 2595.

[13] Y. S. Kim, C. J. An, S. K. Kim, J. Song, and C. S. Hwang, Bull. Korean Chem. Soc., 31 (2010) 2503.

[14] M. S. Kim, K. G. Yim, S. M. Jeon, D. Y. Lee, J. S. Kim, J. S. Kim, J. S. Son, J. Y. Leem, Jpn. J. Appl. Phys., 50 (2011) 035003.

[15] M. S. Kim, K. G. Yim, J. Y. Leem, S. Kim, G. Nam, D. Y. Kim, S. O. Kim, D. Y. Lee, J. S. Kim, and J. S. Kim, J. Korean Phys. Soc., 59 (2011) 346.

[16] D. C. Look, Mater. Sci. Eng. B 80 (2001) 383.

[17] E. M. Mkawi, K. Ibrahim, M. K. M. Ali, M. A. Farrukh and A. S. Mohamed, "The effect of dopant concentration on properties of transparent conducting Al-doped $\mathrm{ZnO}$ thin films for efficient $\mathrm{Cu}_{2} \mathrm{ZnSnS}_{4}$ thin-film solar cells prepared by electrodeposition method", Appl. Nanosci 5 (2015) 993-1001.

[18] J. Jaffe and A. Zunger, "Electronic Structure of the Ternary Pnictide Semiconductors $\mathrm{ZnSiP}_{2}$, $\mathrm{ZnGeP}_{2}, \mathrm{ZnSnP}_{2}, \mathrm{ZnSiAs}_{2}$, and $\mathrm{MgSiP}_{2}$," Physical Review, 28 (1984) 49, (1905) 1882.

[19] H. Kim and CM Gilmore, "Transparent conducting aluminum-doped zinc oxide thin films for organic light-emitting devices”, Appl Phys Lett 76 (2000) 259-261.

[20] C. Mujdat, I. Saliha and C. Yasemin, "The effects of Al doping on the optical constants of ZnO thin films prepared by spray pyrolysis method", 19 (2008) 704-708.

[21] J. I. Pankove, "Optical Process in Semiconductors", Dover Publishing, Inc., New York. (1971).

[22] A. Youssef, L. Abderrazak, H. Bouchaib, R. Abderraouf, T. Philippe, and S. Meryane, "Structural, optical and electrical properties of $\mathrm{ZnO}$ :Al thin films for optoelectronic applications", Opt Quant Electron 46 (2014) 229-234.

[23] D. Bonnell, B. Huey and D. Carroll, "In-Situ Measurement of Electric Fields at Individual Grain Boundaries in TiO2," Solid State Ionics, 75 (1995) 35.

[24] S. Bandyopadhyay, G. K. Paul, S. K. Sen, Sol. Energy Mater. Sol. C. 71 (2002) 103.

[25] S. W. Xue, X. T. Zu, W. G. Zheng, H. X. Deng, and X. Xiang, Physica B. 381 (2006) 209.

[26] M. Nnabuchi, "Optical and Solid State Characterization of Optimized Manganese Sulphide Thin Films and Their Possible Applications in Solar Energy," The Pacific Journal of Science and Technology, 7 (1) (2006) 69-76.

[27] S. K. Min, G. Y. Kwang, Jeong-Sik Son, and Jae-Young Leem, "Effects of Al Concentration on Structural and Optical Properties of Al-doped ZnO Thin Films", Bull. Korean Chem. Soc., 33 (4) (2012) 1235. 